\title{
DESIGN, OPTIMIZATION AND EVALUATION OF ACECLOFENAC FAST DISSOLVING TABLETS EMPLOYING STARCH VALERATE-A NOVEL SUPERDISINTEGRANT
}

\section{R. SANTOSH KUMAR*, SHAMBHAVI KANDUKURI, M. RAMYA, B. KUSUMA LATHA}

GITAM Institute of Pharmacy, GITAM (Deemed to be University), Rushikonda, Vishakhapatnam, A. P. 530045, India

Email: drsantoshrada@gmail.com

Received: 15 Feb 2021, Revised and Accepted: 17 May 2021

\begin{abstract}
Objective: To synthesize, characterize and evaluate starch valerate as a superdisintegrant in the formulation of aceclofenac fast dissolving tablets by employing $2^{3}$ factorial design.
\end{abstract}

Methods: Starch valerate was synthesized and its physical and micromeritic properties were performed to evaluate it. The fast dissolving tablet of aceclofenac was prepared by employing starch valerate as a superdisintegrant in different proportions in each case by direct compression method using $2^{3}$ factorial design for evaluation of tablet parameters like disintegration and dissolution efficiency in 5 min.

Results: The starch valerate prepared was found to be fine, amorphous and free flowing. Starch valerate exhibited good swelling in water with swelling index (125.2\%). The study of starch valerate was shown by fourier transform infrared spectra (FTIR). The drug content (200 $\pm 5 \%)$, hardness $(3.5-4 \mathrm{~kg} / \mathrm{sq} . \mathrm{cm})$, and friability $(<0.15 \%)$ has been effective with regard to all the formulated fast dissolving tablets employing starch valerate. The disintegration time of all the formulated tablets was found to be in the range of $14 \pm 0.04$ to $25.7 \pm 0.02$ sec. The optimized formulation F4 had the least disintegration time i.e., $12.8 \pm 0.02 \mathrm{sec}$. The wetting time of the tablets was found to be in the range of $76 \pm 0.21$ to $217 \pm 0.17 \mathrm{~s}$. The In vitro wetting time was less (i.e., $28 \pm 0.02 \mathrm{~s}$ ) in optimized formulation F4. The water absorption ratio of the formulated tablets was found to be in the range of $46 \pm 0.12$ to $100 \pm 0.27 \%$. The percent drug dissolved in the optimized formulation F8 was found to be $99.93 \%$ in 5 min.

Conclusion: Starch valerate, when combined with sodium starch glycolate, croscarmellose sodium, with aceclofenac, was found to be an effective super disintegrant which improved the dissolution efficiency and could therefore be used in the formulation of quick dissolving tablets to provide immediate release of the contained drug within 5 min.

Keywords: Superdisintegrant, Fast dissolving, Optimization, Starch valerate

(C) 2021 The Authors. Published by Innovare Academic Sciences Pvt Ltd. This is an open access article under the CC BY license (https://creativecommons.org/licenses/by/4.0/) DOI: https://dx.doi.org/10.22159/ijap.2021v13i4.41122. Journal homepage: https://innovareacademics.in/journals/index.php/ijap

\section{INTRODUCTION}

A numerous developments have been done in different dosage forms from ages and the most popular solid dosage forms were being tablets and capsules [1]. A lot of research was being done from many years in order to acquire many drugs to today's world and among them the fast disintegrating tablets were chosen to make available over the counter as it avoids the swallowing problems and were first developed in the late $1970 \mathrm{~s}$ as an alternative to conventional dosage forms [2] due to greater bioavailability [3]. Fast dissolving tablets were the dosage forms that disintegrate quickly so to release the drug, disperse and dissolve when placed on tongue [4], with the aid of superdisintegrant. Thus these formulations became an alternative dosage form to geriatrics, paediatrics and also to those people who were bedridden, mentally unwell, fear of swallowing.

United States Food and Drug Administration (USFDA) outlined them as "A solid dose type containing a medicative substance or active ingredient that disintegrate quickly sometimes in a matter of seconds once placed upon the tongue" [5]. Fast dissolving tablets may also be known as mouth dissolving tablets, rapid dissolving, melt-in mouth tablets, or dispersible tablets, quick disintegrating tablets [6].

Aceclofenac was proved to be an effective NSAID with lower indication gastro-intestinal adverse effects and thus resulted in great compliance in treatment $[7,8]$, hence used in treatment of rheumatoid arthritis, osteoarthritis and ankylosing spondylitis, muscular skeletal studies, dental pain, postoperative pain, posttraumatic pain, low back pain, and gynaecological pain etc. [9].

The main objective of this work was to formulate and characterize fast dissolving tablets of aceclofenac fast dissolving tablets employing starch valerate-a novel superdisintegrant prepared by modification of starch, sodium starch glycolate, crospovidone as superdisintegrants by using optimization techniques. A $2^{3}$ factorial design was applied to investigate the interaction effects of three variables i.e., starch valerate (A), sodium starch glycolate (B), crospovidone $(\mathrm{C})$ in each case so as to find the formula with that of less disintegration time and more dissolution efficiency and to permit arbitrary selection of tablets with immediate release of drug within 5 min.

\section{MATERIALS AND METHODS}

Valeric acid was bought from Lotus Chemicals Ltd, Chennai. Methanol was gifted from Thermo Fischer chemicals Ltd, Mumbai. Potato starch, aceclofenac and crosspovidone were obtained from Yarrow chem. Products, Mumbai. Distilled water, Mannitol was purchased from Finar chemicals Ltd, Ahmedabad. Microcrystalline cellulose was purchased from Qualigens fine chemicals, Mumbai). Talc and Magnesium stearate were obtained from Molychem, Mumbai.

\section{Methods}

\section{Preparation of starch valerate (A novel superdisintegrant)}

Potato starch was slurried using distilled water in a beaker and valeric acid was added to it, stirred continuously so that the potato slurry gets mixed properly. Then, the slurry was checked for $\mathrm{pH}$ and adjusted to 3.5 by adding $10 \mathrm{M}$ sodium hydroxide solution and was then conditioned for $16 \mathrm{~h}$ at $60^{\circ} \mathrm{C}$. After conditioning, the unreacted valeric acid was drained and the solution remained was washed with distilled water and allowed to dry in the oven at $60^{\circ} \mathrm{C}$ for around $2 \mathrm{~h}$. The dried solid mass was then sieved with sieve no. \#120. The obtained fine powder was Starch Valerate [10]. 


\section{Characterization of starch valerate (Novel superdisintegrant):}

The prepared starch valerate was evaluated for the following;

\begin{tabular}{|c|c|c|}
\hline - Solubility & $:$ & $\begin{array}{l}\text { The solubility of starch valerate was tested in water, aqueous buffer solutions at different } \mathrm{pH} \text { of } 1,2,3,4,5,6 \text { and } 7 \text {. Also te sted } \\
\text { in organic solvents such as alcohol, dichloromethane, chloroform, acetone, petroleum ether etc. [11]. }\end{array}$ \\
\hline $\mathrm{pH}$ & : & rch valerate was made into $1 \% \mathrm{w} / \mathrm{v}$ of dispersion or \\
\hline Viscosity & : & 11]. \\
\hline $\begin{array}{l}\text { - Swelling } \\
\text { Index }\end{array}$ & : & $\begin{array}{l}\text { Two } 10 \mathrm{ml} \text { graduated tubes were taken; starch valerate was added into them till } 1 \mathrm{ml} \text { marking. In one test tube distilled water } \\
\text { and liquid paraffin into the other tube was poured and mixed well by shaking. The obtained dispersion was allowed to stand } \\
\text { for } 12 \mathrm{~h} \text { and readings were noted. The sediment volumes in the tubes were recorded. The swelling index was calculated as } \\
\text { follows [11]. }\end{array}$ \\
\hline & & S. I $(\%)=\frac{V_{w}-V_{L}}{V_{L}} \times 100$ \\
\hline & & $\mathrm{V}_{\mathrm{w}}:$ Volume of sediment in wate \\
\hline & & $\mathrm{V}_{\mathrm{L}:}^{\text {Volume of sediment in light liquid paraffin }}$ \\
\hline $\begin{array}{l}\text { - Gelatinizati } \\
\text { on }\end{array}$ & : & $\begin{array}{l}\text { h valerate were prepared for evaluating the gelling property i.e., gelatinization by } \\
{ }^{\circ} \mathrm{C} \text { for } 30 \mathrm{~min}[11] \text {. }\end{array}$ \\
\hline Particle size & : & The pr \\
\hline Dens & : & \\
\hline $\begin{array}{l}\text { Bulk } \\
\text { ensity }\end{array}$ & : & $\begin{array}{l}\text { Two graduated cylinders were taken, starch in one and starch valerate in another were taken for determining bulk density } \\
\text { (gm/cc) by tapping method [11]. }\end{array}$ \\
\hline $\begin{array}{l}\text { Angle of } \\
\text { pose }\end{array}$ & : & $\begin{array}{l}\text { Placing a funnel at appropriate height with the help of a stand, starch as well as starch valerate was passed through the } \\
\text { funnel, and markings were drawn, measured with scale and calculated [11]. }\end{array}$ \\
\hline $\begin{array}{l}\text { - Compressib } \\
\text { ility index }\end{array}$ & : & $\begin{array}{l}\text { By placing the two graduated cylinders containing starch and starch valerate into Bulk density apparatus and allowed to tap } \\
\text { for } 100 \text { times, readings were noted [11] and calculated by using the following equation; }\end{array}$ \\
\hline & & Compressibility index $(\mathrm{CI})=\frac{\mathrm{V}_{0}-\mathrm{V}}{\mathrm{V}}$ \\
\hline & & \\
\hline $\begin{array}{l}\text { - Melting } \\
\text { Point }\end{array}$ & : & $\begin{array}{l}\text { Some amount of starch valerate was taken into the capillary tube, then placed into the melting point apparatus to determine } \\
\text { the melting point [11]. }\end{array}$ \\
\hline - FTIR & : & $\begin{array}{l}\text { spectra of starch valerate was recorded in FTIR i.e., Fourier Transform Infrar } \\
\text { assium bromide }(\mathrm{KBr}) \text { disks by means of a hydrostatic press at 6-8 tons press }\end{array}$ \\
\hline Ester t & $:$ & $\begin{array}{l}\text { In a test tube, starch valerate }(1 \mathrm{mg}) \text {, ethanol }(1 \mathrm{ml}),(\mathrm{NaOH}) \text { sodium hydroxide }(0.1 \mathrm{ml}) \text { were taken and as an indicator } \\
\text { phenolphthalein was added. The colour change was observed [11]. }\end{array}$ \\
\hline
\end{tabular}

\section{Preparation of aceclofenac fast dissolving tablets}

By direct compression method using starch valerate, the aceclofenac quick dissolving tablets were prepared using $2^{3}$ factorial designs in which 3 independent variables [3 superdisintegrants i.e. starch valerate (A), sodium starch glycolate (B), crospovidone (C)] and 5 dependent variables [percentage dissolved in $5 \mathrm{~min}$, dissolution efficiency in $5 \mathrm{~min}$, wetting time, water absorption ratio, disintegration time] were applied. Table 1, in which superdisintegrants were selected at 2 stages, i.e. higher and lower, shows the composition of the different formulations of aceclofenac rapid dissolving tablets. 5\% concentration of starch itaconate (A), sodium starch glycolate (B) and crospovidone (C) at the higher level, and $0 \%$ concentration of starch velarate $(\mathrm{A})$, sodium starch glycolate (B) and sodium starch glycolate (B),crospovidone (C) at lower level. Each ingredient was passed through the \# 120 mesh sized screen before mixing for uniformity in particle size. Starch valerate, sodium starch glycolate, crospovidone, mannitol, and microcrystalline cellulose were precisely weighed and combined and added to aceclofenac using mortar and pestle. Finally, a powder mixture was applied with talc and magnesium stearate. Lastly, the mixed mixture was compressed by using eight station rotator (Presshakthi Machineries Pvt, Ltd., Ahmedabad, India) [12].

Table 1: Formulae of aceclofenac fast dissolving tablets employing starch valerate

\begin{tabular}{|c|c|c|c|c|c|c|c|c|}
\hline Ingredients (mg per tablet) & F1 & F2 & F3 & F4 & F5 & F6 & F7 & F8 \\
\hline Aceclofenac & 100 & 100 & 100 & 100 & 100 & 100 & 100 & 100 \\
\hline Starch valerate & - & 25 & - & 25 & - & 25 & - & 25 \\
\hline Sodium Starch Glycolate & - & - & 25 & 25 & - & - & 25 & 25 \\
\hline Crospovidone & - & - & - & - & 25 & 25 & 25 & 25 \\
\hline Mannitol & 130 & 105 & 105 & 80 & 105 & 80 & 80 & 55 \\
\hline Micro Crystalline Cellulose & 250 & 250 & 250 & 250 & 250 & 250 & 250 & 250 \\
\hline Talc & 10 & 10 & 10 & 10 & 10 & 10 & 10 & 10 \\
\hline Magnesium Stearate & 10 & 10 & 10 & 10 & 10 & 10 & 10 & 10 \\
\hline Total Weight of the tablet & 500 & 500 & 500 & 500 & 500 & 500 & 500 & 500 \\
\hline
\end{tabular}

\section{Evaluation of aceclofenac fast dissolving tablets}

\section{Hardness}

The strength required in a diametric manner to split the tablet is called tablet hardness. It is usually measured using the Monsanto hardness tester, which causes the strength to fall diametrically on the tablet with the aid of its built-in spring. This was expressed in terms of $\mathrm{kg} / \mathrm{cm}^{2}$ [13].

\section{Uniformity of weight}

For weight variation test to be done, 20 tablets were taken. The individual variation of tablet weight from the average weight of 20 tablets was considered to be the weight variation [13].

\section{Average weight of tablet}

$80 \mathrm{mg}$ or less

More than $80 \mathrm{mg}$ or less than $125 \mathrm{mg}$

$125 \mathrm{mg}$ or less
\% Deviation

$\pm 10$

$\pm 7.5$

$\pm 5$ 


\section{Friability}

The tablets were initially weighed and then put into the Roche friabilator for friability calculation, where the tablets were allowed to rotate for $4 \mathrm{~min}$ or up to 100 revolutions at $25 \mathrm{rpm}$. After removal from the friabilator, the tablets were weighed again and the percentage of weight loss was determined [13] using the formula below,

$$
\mathrm{F}=\frac{100 \times W(\text { initial })-W(\text { final })}{W(\text { initial })}
$$

\section{Drug content uniformity}

10 tablets were weighed and powdered to determine the uniformity of the drug content. Powder equivalent to $10 \mathrm{mg}$ of the medication, i.e., aceclofenac was extracted and filtered into a 7.4 phosphate buffer, whereby the aceclofenac content was determined by spectrophotometric absorption measurement at $274 \mathrm{~nm}$ after sufficient dilution with a 7.4 phosphate buffer and was measured as an average of three determinations [13].

\section{Wetting time}

By taking a petri dish of about $10 \mathrm{~cm}$ in diameter and five tissue papers and an amaranth solution (water soluble dye-for color), the wetting time can be determined. The tissue paper was put in the petri dish and about $10 \mathrm{ml}$ of amaranth solution was poured into it, so that the color solution would be absorbed by the tissue paper. Then, the tablets were placed individually on the surface of the tissue paper and the time taken by the tablet to absorb the color was noted [13].

\section{Water absorption ratio}

The same wetting time method was followed to find out the water absorption ratio, but after the tablet absorbs the color water, the tablet should be re-weighted and the following formula should be used [13].

$$
\mathrm{R}=\frac{100\left(\mathrm{~W}_{\mathrm{a}}-\mathrm{W}_{\mathrm{b}}\right)}{\mathrm{W}_{\mathrm{b}}}
$$

Where,

\section{$\mathrm{W}_{\mathrm{a}}$-weight of tablet after water absorption}

$\mathrm{W}_{\mathrm{b}}$-weight of tablet before water absorption

\section{In-vitro disintegration time}

The prepared tablets were placed into the disintegration testing apparatus (LABINDIA) containing $900 \mathrm{ml}$ of the 7.4 phosphate as the disintegration media, maintained at a temperature range of $37 \pm 0.2$ ${ }^{\circ} \mathrm{C}$. The time taken by the tablet for complete disintegration with no solid, palatable mass in the apparatus was recorded [13].

\section{In-vitro dissolution studies}

An 8-stage dissolution apparatus (Electro-Lab, TDT-08L) was used to study the dissolution of aceclofenac fast dissolving tablets. Before dropping the tablets into the apparatus for testing, the buffer (7.4 pH-phosphate buffer) of $900 \mathrm{ml}$ was poured into each basket and it should be reach with the temperature required i.e., $37 \pm 0.5{ }^{\circ} \mathrm{C}$, paddles should be fitted and rpm was set to 50rpm. Once the apparatus was all set to use, the tablets were dropped, at predetermined time intervals the samples of $5 \mathrm{ml}$ were collected, filtered, diluted if required and assayed at $274 \mathrm{~nm}$ using Shimadzu UV-1800 UV/Visible Scanning Spectrophotometer. Cumulative percentage release was calculated using standard absorbance from the calibration curve. All the dissolution experiments were conducted in triplicate $(n=3)$ [13].

\section{Factorial design}

The present study used factorial design to evaluate the individual and combined effects. The formulation contains three superdisintegrants and therefore, to evaluate these effects a $2^{3}$ factorial design was applied. The parameters of fast dissolving tablets (disintegration and dissolution efficiency in $5 \mathrm{~min}$ ) were analysed as per ANOVA of $2^{3}$ factorial design. Contour plots and surface plots were drawn with the help of Design Expert 7.11 version software. Based on the results of statistical analysis, the optimum formulation was selected.

\section{Comparison of optimized formulation with marketed formulation}

The optimized formulation was compared with marketed formulation (ACECLO) containing $100 \mathrm{mg}$ of aceclofenac after removal of film coating.

\section{Label claim of marketed formulation}

Each ACECLO film coated tablet of $100 \mathrm{mg}$ contains titanium dioxide as colour of the tablet to protect from light, moisture and temperature. The tablets used for the experiment were manufactured by ARISTO Pharmaceuticals Pvt. Ltd., Makhnumajra village, Baddi district, Himachal Pradesh-173205 bearing $\mathrm{M} / 736 / 2016$ as manufacturing license number that belongs to 5340K028 batch. The tablets manufactured date was 10/2019 and expiry date was $09 / 2020$.

\section{RESULTS AND DISCUSSION}

The prepared starch valerate was found to be fine, amorphous and free-flowing powder. It was insoluble in water, aqueous buffers $(\mathrm{pH}$ $1,2,3,4,5,6$ and 7 ) and also in organic solvents (methanol, petroleum ether, dichloromethane, and chloroform) which were tested with $1 \%$ $\mathrm{w} / \mathrm{v}$ of starch valerate dispersion. Also, its physical and micromeritic properties were analysed, indicated good flow and compressibility properties which were needed for a solid dosage form to manufacture and results were summarized in table 2 .

Starch valerate had exhibited good swelling property in water when compared to swelling in light liquid paraffin. The swelling index was $125.2 \%$. The density of starch valerate was found to be 0.9908 $\mathrm{gm} / \mathrm{cc}$. The FTIR spectra of starch and starch valerate were shown in fig. 1 and 2 . The presence of peaks absorption at $1639.97 \mathrm{~cm}^{-1}$, which was a characteristic peak of ester, so from FTIR studies it was concluded that starch valerate (ester) was formed when starch was allowed to react with valeric acid.

The test for ester was performed and disappearance of pink colour confirmed the presence of ester i.e., starch valerate. When starch valerate was taken into capillary tube, for testing its melting point using melting point apparatus, it was found to melt at $182.6^{\circ} \mathrm{C}$.

Table 2: Physical and micromeritic properties of prepared novel superdisintegrant-starch valerate

\begin{tabular}{ll}
\hline Parameters & Observation \\
\hline Solubility & Insoluble in all aqueous and organic solvents that were tested. \\
pH & $3.48 \pm 0.02$ \\
Viscosity & $1.0680 .008 \mathrm{cps}$ \\
Swelling index (S. I) & $125.2 \%$ \\
Gelling property & Np gelation of starch valerate particles, whereas starch particles formed gel. \\
Particle size & $5.82 \pm 2.124 \mu \mathrm{m}$ \\
Density & $0.9908 \pm 0.0004 \mathrm{gm} / \mathrm{cc}$ \\
Bulk density & $0.52 \pm 0.03 \mathrm{gm} / \mathrm{cc}$ \\
Angle of repose & $13.399^{\circ}$ (good) \\
Compressibility index (CI) & $25 \pm 0.01$ \\
Melting point & $182.6^{\circ} \mathrm{C}$ \\
\hline
\end{tabular}

*SD Standard Deviation from mean, $n=3$, mean \pm SD. 


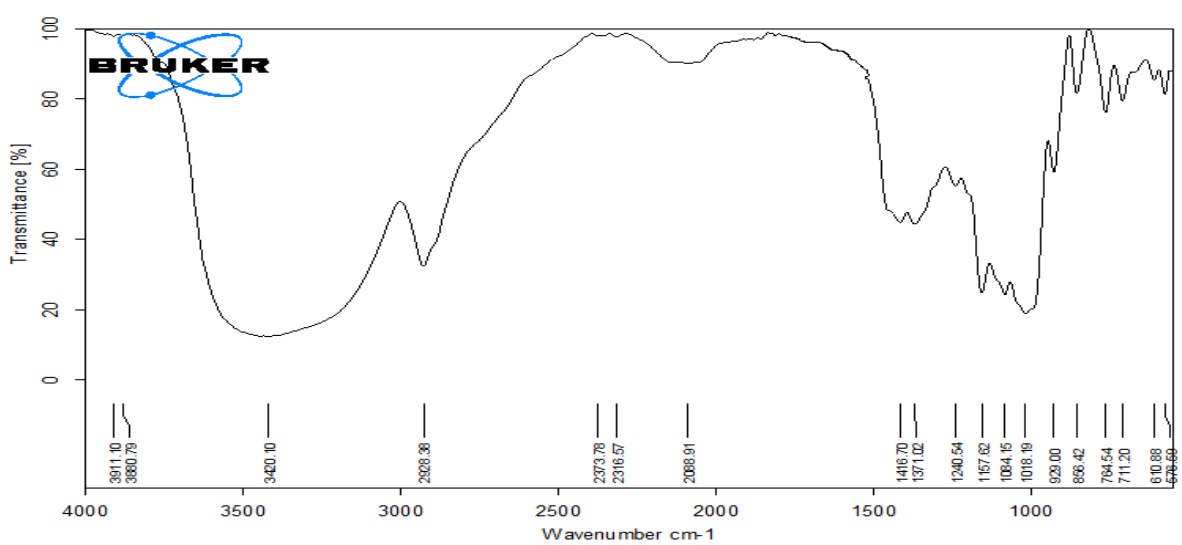

Fig. 1: FTIR spectra of potato starch

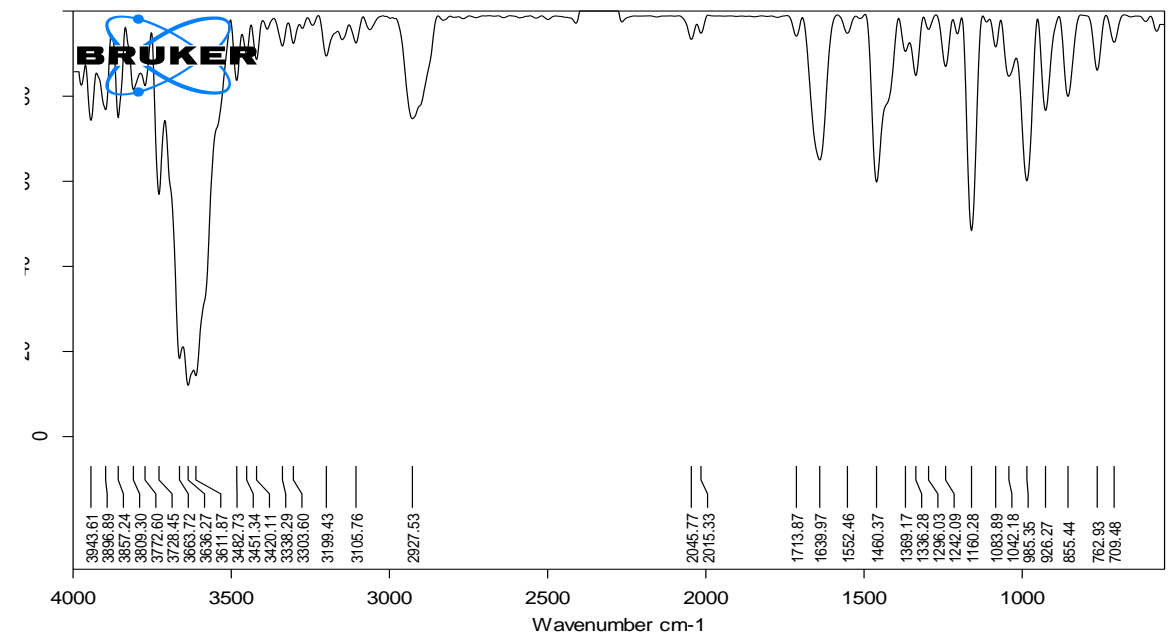

Fig. 2: FTIR spectra of starch valerate

\section{Evaluation of tablets}

\section{Hardness}

The tablet hardness of the optimized formulation as well as marketed were in the range of $3.5-4 \mathrm{~kg} / \mathrm{cm}^{2}$, indicates good strength with a capability to resist its physical and pre-functionary stress conditions during travelling and handling. The harness of tablet was greater when compared with the hardness of the tablets i. e 1.23$1.63 \mathrm{~kg} / \mathrm{cm}^{2}$ prepared by Vivek Dave et al. [14].

\section{Friability}

By performing friability test to all the optimized formulations as well as marketed formulation, the weight loss was found to be less than $0.15 \%$ indicating good mechanical resistance of tablets. Thus, it was proved that tablets could withstand the pressure, mechanical shocks during handling, transportation, storage and manufacturing processes. The friability loss was relatively less when compared with the friability of tablets i. e $0.15-0.72 \%$ prepared by C. Mallikarjuna Setty, et al. [15]

\section{Drug content}

The prepared fast dissolving tablets containing aceclofenac claimed within $200 \pm 5 \%$ of that of the label which was higher in comparison to the drug content of tablets i. e $95 \pm 5 \%$ prepared by Keshav R. Deshmukh, et al. [16].

\section{Wetting time and water absorption ratio}

Wetting time and water absorption ratio of tablets formulated as well as marketed resulted to be within the limits that were prescribed and obeyed the criteria of fast dissolving tablets. The wetting time at initial and final times were depicted in the fig. 3. The optimized formulation F-8 had shown less wetting time i. e $25 \pm 0.17$ seconds when compared to other formulations and marketed formulation which was less when compared to the wetting of tablets that ranged from $29.62 \pm 0.87$ to $32.66 \pm 1.87$ seconds which were prepared by Jyotsana Madan, et al. [17]. The water absorption ratio was found to be $100 \pm 0.27 \%$ which was relatively more when compared to the water absorption ratio of tablets i. e $74.48 \%$ prepared by Kalpesh Gaur A [18].

\section{In-vitro disintegration time}

As mentioned in the table 3 , the disintegration time of all formulated tablets and marketed formulation was laid between $14.0 \pm 0.04$ to $25.7 \pm 0.02$ seconds which was comparatively lesser the disintegration time of tablets i. e 18-40 seconds prepared by Anas Bahnassi et al. [19].

\section{In-vitro dissolution studies}

From in vitro dissolution studies of fast dissolving tablets containing aceclofenac employing starch valerate, their profile was shown in fig. 4(a) and 4(b) and the optimized formulation with marketed formulation dissolution profile was compared as given in table 4 and 5. The dissolution parameters of all the formulations i.e., F-1 to F-8 and marketed formulations were given in table 4, whereas the optimized formulation i.e., F-8 had shown more $\mathrm{PD}_{5}$ (percent dissolved in $5 \mathrm{~min}$ ) which contains $5 \%$ starch valerate, sodium starch glycolate and crospovidone was found to be $99.93 \pm 0.11 \%$ which was more when compared to the percent dissolved of tablets 
i. e $99.5 \%$ which were prepared by Garala Kevin C et al. [20]. Even $\mathrm{DE}_{5 \%}$ (dissolution efficiency in $5 \mathrm{~min}$ ) was shown more in the optimized formulation, F-8.

The $\mathrm{PD}_{5}$ and $\mathrm{DE}_{5 \%}$ reveals that tablets were effective at $5 \%$ starch valerate, $5 \%$ sodium starch glycolate and $5 \%$ crospovidone, when the formulations were made by direct compression using these superdisintegrants. The number of folds in $\mathrm{DE}_{5 \%}$ was given in the table 4. Therefore, from the results it was concluded that starch valerate (novel superdisintegrant) could be used as superdisintegrant in the formulation of fast dissolving tablets of aceclofenac.

Table 3: Comparison of physical properties: Hardness, friability, drug content, disintegration time, wetting time, water absorption ratio of aceclofenac fast dissolving tablets employing starch itaconate with marketed formulation

\begin{tabular}{llllll}
\hline Formulation & $\begin{array}{l}\text { Hardness } \\
\left(\mathbf{k g} / \mathbf{c m}^{2}\right) \mathbf{n} \pm \mathbf{S D}\end{array}$ & $\begin{array}{l}\text { Friability (\%) } \\
\mathbf{n} \pm \text { SD }\end{array}$ & $\begin{array}{l}\text { Drug content } \\
\mathbf{m g} / \mathbf{t a b}) \mathbf{n} \pm \text { SD }\end{array}$ & $\begin{array}{l}\text { Disintegration } \\
\text { time (sec) } \mathbf{n} \pm \mathbf{S D}\end{array}$ & $\begin{array}{l}\text { Wetting time } \\
(\mathbf{s e c}) \mathbf{n} \pm \mathbf{S D}\end{array}$ \\
\hline F1 & $3.6 \pm 0.01$ & $0.11 \pm 0.013$ & $96.12 \pm 0.71$ & $25.7 \pm 0.02$ & $\begin{array}{l}\text { Water absorption } \\
\text { ratio (\%) } \mathbf{n} \pm \mathbf{S D}\end{array}$ \\
F2 & $3.5 \pm 0.03$ & $0.12 \pm 0.015$ & $97.48 \pm 0.79$ & $18 \pm 0.03$ & $42 \pm 0.02$ \\
F3 & $3.6 \pm 0.01$ & $0.13 \pm 0.012$ & $98.10 \pm 0.63$ & $19 \pm 0.02$ & $29 \pm 0.12$ \\
F4 & $3.7 \pm 0.04$ & $0.12 \pm 0.014$ & $98.32 \pm 0.55$ & $12.8 \pm 0.02$ & $27 \pm 0.09$ \\
F5 & $3.6 \pm 0.03$ & $0.12 \pm 0.012$ & $99.23 \pm 0.56$ & $14 \pm 0.01$ & $28 \pm 0.02$ \\
F6 & $3.9 \pm 0.01$ & $0.13 \pm 0.012$ & $99.45 \pm 0.18$ & $17 \pm 0.02$ & $22 \pm 0.21$ \\
F7 & $3.8 \pm 0.02$ & $0.11 \pm 0.014$ & $99.56 \pm 0.57$ & $13 \pm 0.01$ & $25 \pm 0.09$ \\
F8 & $3.8 \pm 0.04$ & $0.11 \pm 0.013$ & $99.79 \pm 0.11$ & $15 \pm 0.02$ & $28 \pm 0.15$ \\
Marketed & $3.9 \pm 0.01$ & $0.12 \pm 0.012$ & $99.12 \pm 0.11$ & $14 \pm 0.04$ & $25 \pm 0.17$ \\
formulation & & & & & $23 \pm 0.19$
\end{tabular}

*SD Standard Deviation from mean, $\mathrm{n}=3$, mean \pm SD.

Fig. 3: Wetting times of aceclofenac fast dissolving tablets (employing starch valerate)

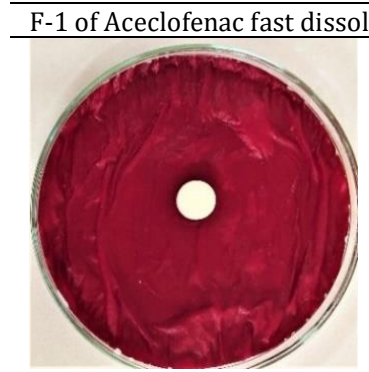

At time $=0 \mathrm{sec}$

F-3 of Aceclofenac fast dissolving tablet

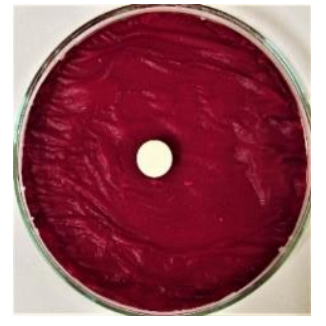

At time $=0 \mathrm{sec}$

F-5 of Aceclofenac fast dissolving tablet

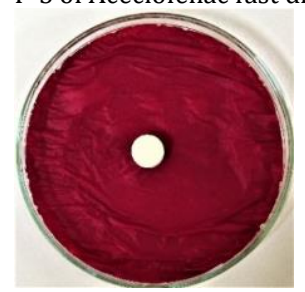

At time $=0 \mathrm{sec}$

F-7 of Aceclofenac fast dissolving tablet

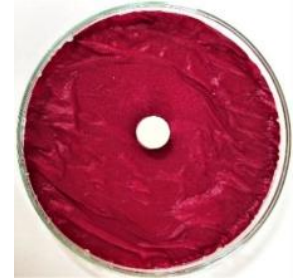

At time $=0 \mathrm{sec}$

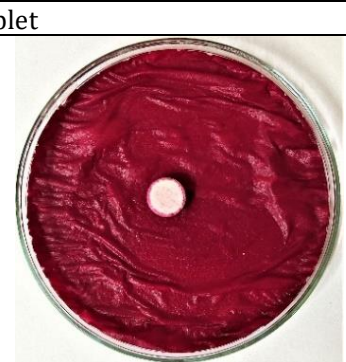

At time $=42 \mathrm{sec}$

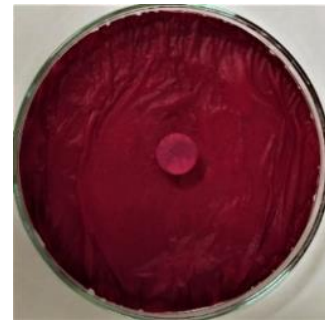

At time $=27 \mathrm{sec}$

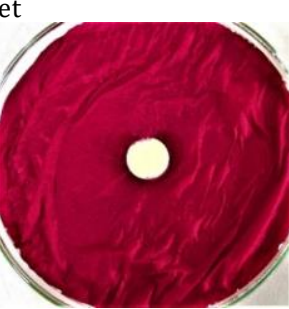

At time $=22 \mathrm{sec}$

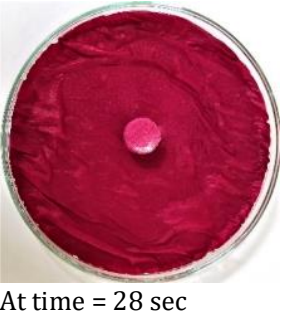

F-2 of Aceclofenac fast dissolving tablet

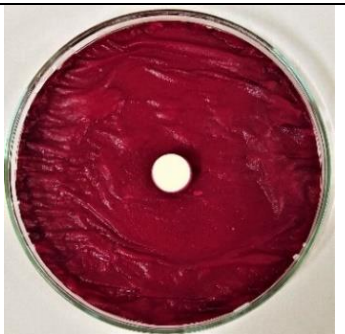

At time $=0 \mathrm{sec}$

F-4 of Aceclofe

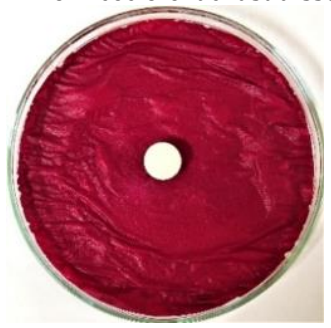

At time $=0 \mathrm{sec}$

F-6 of Aceclofenac fast dissolving tablet

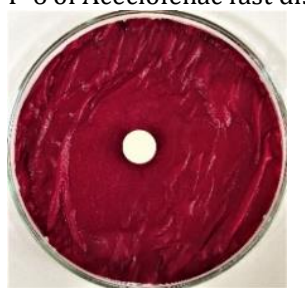

At time $=0 \mathrm{sec}$

F-8 of Aceclofenac fast dissolving tablet

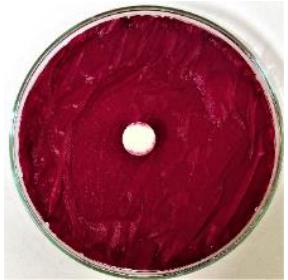

At time $=0 \mathrm{sec}$

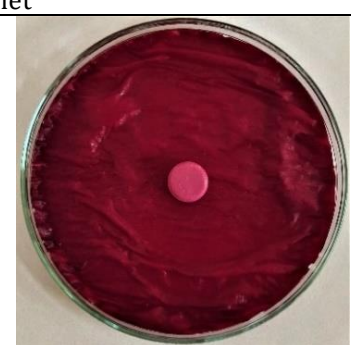

At time $=29 \mathrm{sec}$

let

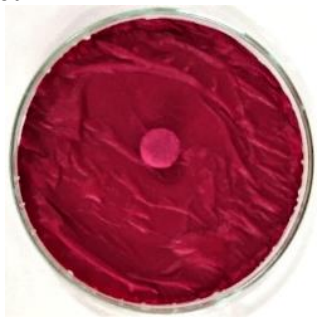

At time $=28 \mathrm{sec}$

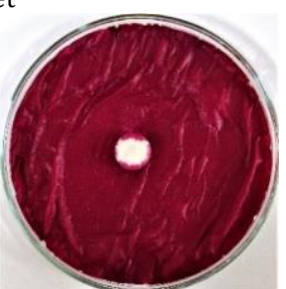

At time $=25 \mathrm{sec}$

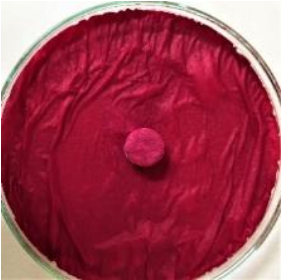

At time $=25 \mathrm{sec}$ 
Table 4: Comparison of dissolution parameters of aceclofenac fast dissolving tablets formulated employing starch valerate and other known superdisintegrants with marketed formulation

\begin{tabular}{|c|c|c|c|c|c|c|c|c|c|}
\hline Time (min) & F-1 & F-2 & F-3 & F-4 & F-5 & F-6 & F-7 & F-8 & $\begin{array}{l}\text { Marketed } \\
\text { formulation }\end{array}$ \\
\hline $\mathrm{PD}_{5}$ & $04.94 \pm 0.12$ & $25.98 \pm 013$ & $27.07 \pm 0.17$ & $49.20 \pm 0.18$ & $60.49 \pm 0.15$ & $63.26 \pm 0.12$ & $51.55 \pm 0.14$ & $99.93 \pm 0.11$ & $75.20 \pm 0.13$ \\
\hline $\mathrm{DE}_{5} \%$ & $4.4 \pm 0.11$ & $21.8 \pm 0.09$ & $25.2 \pm 0.05$ & $49.2 \pm 0.12$ & $57.8 \pm 0.14$ & $64.4 \pm 0.08$ & $84.2 \pm 0.13$ & $95.4 \pm 0.01$ & $28.32 \pm 0.12$ \\
\hline $\begin{array}{l}\text { No of folds } \\
\text { increase in } \mathrm{DE}_{5} \%\end{array}$ & - & 4.95 & 5.72 & 11.18 & 13.13 & 14.63 & 10.95 & 21.68 & --- \\
\hline
\end{tabular}

*SD Standard Deviation from mean, $\mathrm{n}=3$, mean \pm SD, $\mathrm{PD}_{5}$-Percent dissolved in 5 min, $\mathrm{DE}_{5 \%}$-Dissolution efficiency in 5 min,

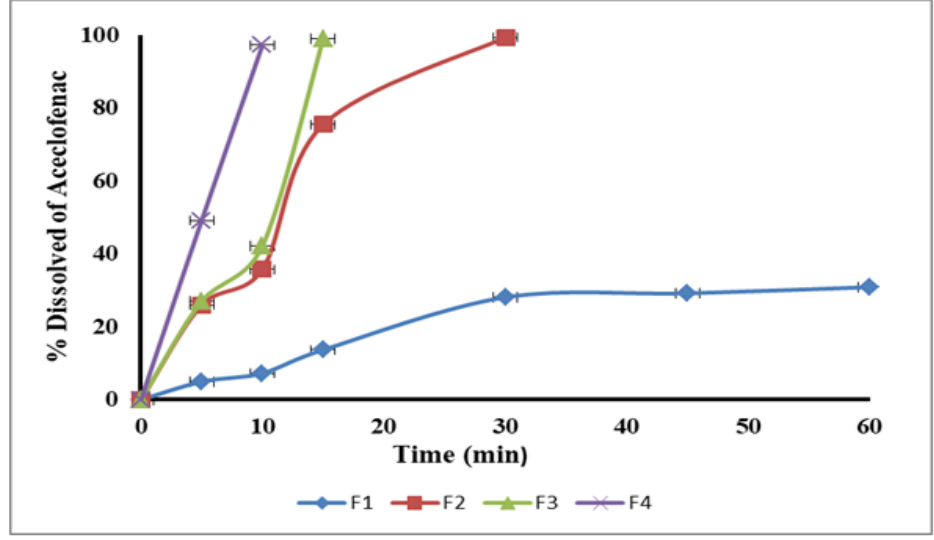

Fig. 4 (a): Dissolution profiles of aceclofenac fast dissolving tablets prepared employing starch valerate (F1-F4)

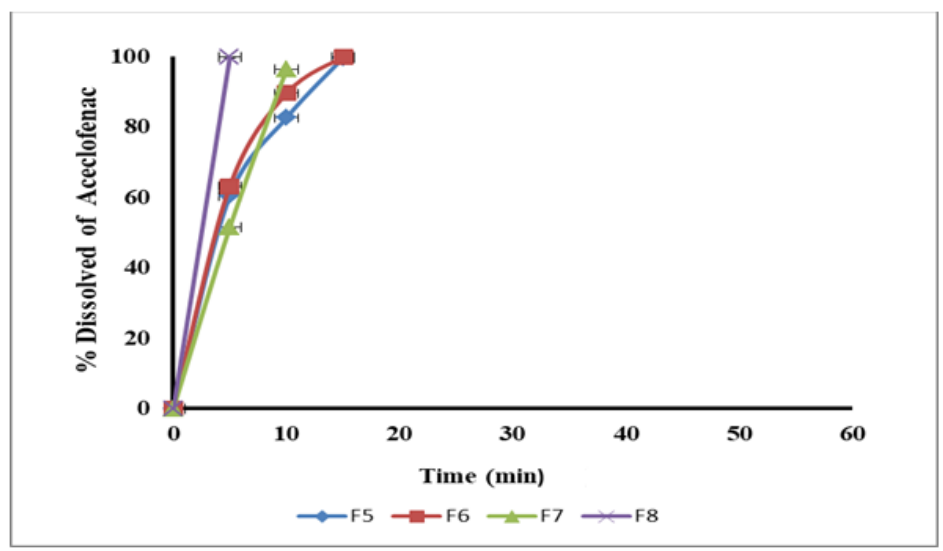

Fig. 4(b): Dissolution profiles of aceclofenac fast dissolving tablets prepared employing starch valerate (F5-F8)

Table 5: Comparison of aceclofenac percent dissolved from dissolving tablets employing starch valerate with marketed formulation

\begin{tabular}{|c|c|c|c|c|c|c|c|c|c|}
\hline $\begin{array}{l}\text { Time } \\
\text { (min) }\end{array}$ & F1 & F2 & F3 & F4 & F5 & F6 & F7 & F8 & $\begin{array}{l}\text { Marketed } \\
\text { formulation }\end{array}$ \\
\hline 5 & $04.94 \pm 0.12$ & $25.98 \pm 0.13$ & $27.07 \pm 0.17$ & $49.20 \pm 0.18$ & $60.49 \pm 0.15$ & $63.26 \pm 0.12$ & $51.55 \pm 0.14$ & $99.93 \pm 0.11$ & $75.20 \pm 0.13$ \\
\hline 10 & $07.26 \pm 0.11$ & $35.78 \pm 0.12$ & $42.18 \pm 0.10$ & $97.30 \pm 0.15$ & $82.69 \pm 0.10$ & $89.65 \pm 0.11$ & $96.48 \pm 0.12$ & --- & $88.21 \pm 0.10$ \\
\hline 15 & $13.69 \pm 0.10$ & $75.53 \pm 0.11$ & $99.00 \pm 0.02$ & --- & $99.74 \pm 0.08$ & $99.94 \pm 0.02$ & -- & --- & $99.32 \pm 0.24$ \\
\hline 30 & $28.11 \pm 0.20$ & $99.42 \pm 0.09$ & --- & --- & --- & --- & --- & --- & -- \\
\hline 45 & $29.18 \pm 0.18$ & --- - & --- & --- & --- & --- & --- & --- & --- \\
\hline 60 & $30.89 \pm 0.12$ & --- & --- & --- & --- & --- & --- & --- & --- \\
\hline
\end{tabular}

*SD Standard Deviation from mean, $n=3$, mean \pm SD.

The disintegration time and dissolution efficiency in $10 \mathrm{~min}$ indicates that the dependant variables strongly depend on the independent variables.

The fitted equations relating the disintegration time and dissolution efficiency by the end of 5 min to the transform factors were shown in the following equations,

Disintegration time $=+45.88+3.38 \mathrm{~A}-5.63 \mathrm{~B}-5.13 \mathrm{C}+0.63 \mathrm{AB}-0.37 \mathrm{AC}-$ $2.12 \mathrm{BC}+1.12 \mathrm{ABC} .\left(\mathrm{R}^{2}=1.000\right)$
Dissolution efficiency in $5 \mathrm{~min}=+28.76+11.96 \mathrm{~A}+10.26 \mathrm{~B}+$ $16.34+9.01 \mathrm{AB}+6.64 \mathrm{AC}+4.39 \mathrm{BC}+8.04 .\left(\mathrm{R}^{2}=1.000\right)$

The value of the $\mathrm{R}^{2}$ indicates the good fit. The polynomial equations can be used to draw a conclusion after considering the magnitude of coefficient and the mathematical sign it carries (Positive or Negative). Once the polynomial equation, which relate the levels of each factor and their corresponding interactions with disintegration time and percent release in $5 \mathrm{~min}$, the surface response curves and contour plots were constructed using software. 


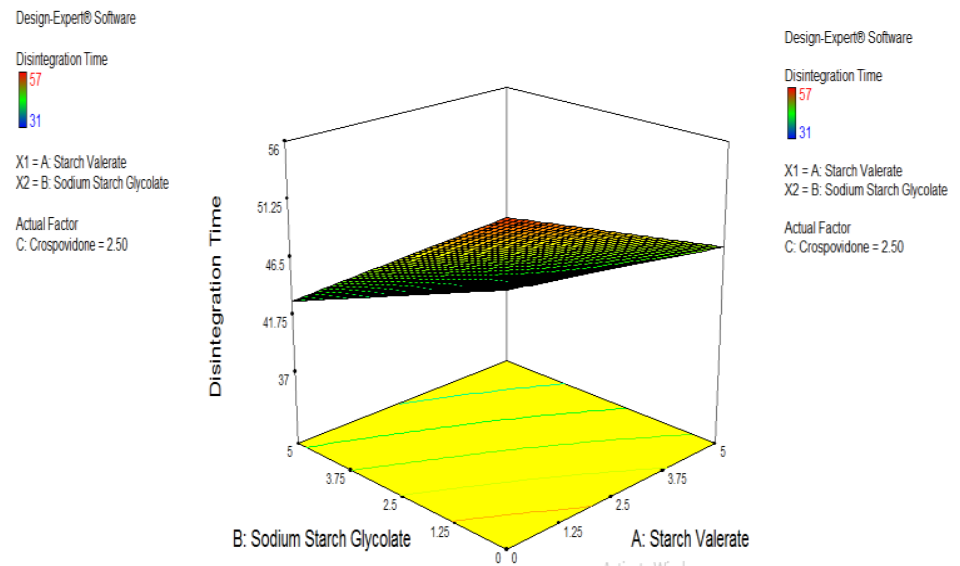

A) Surface plot

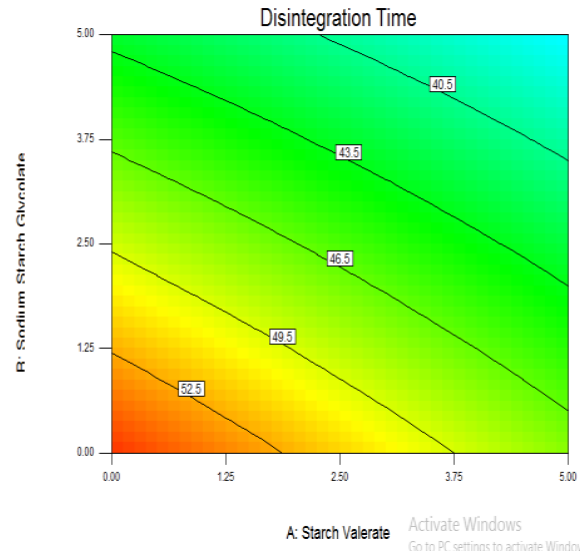

B) Counter plot

Fig. 5.1: A. Surface plot, B. Contour plot of Aceclofenac fast dissolving tablets (Effect of Starch Valerate and Sodium starch glycolate on disintegration time)

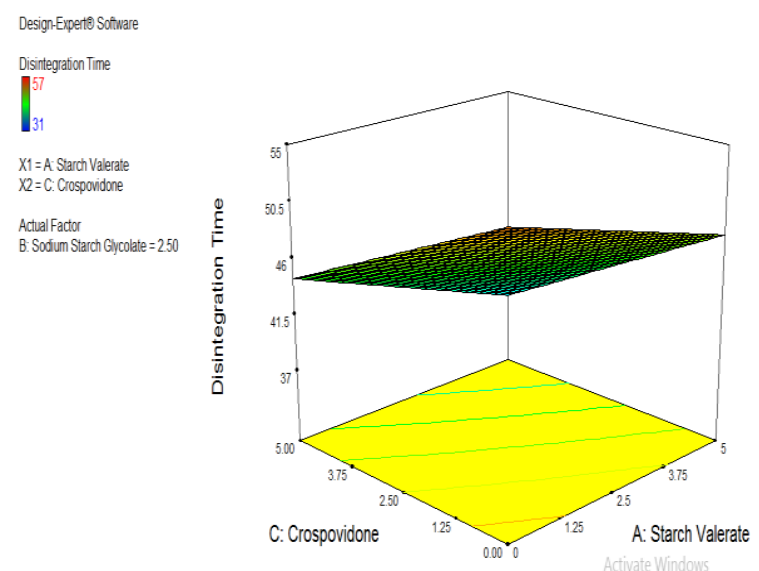

(A) Surface plot
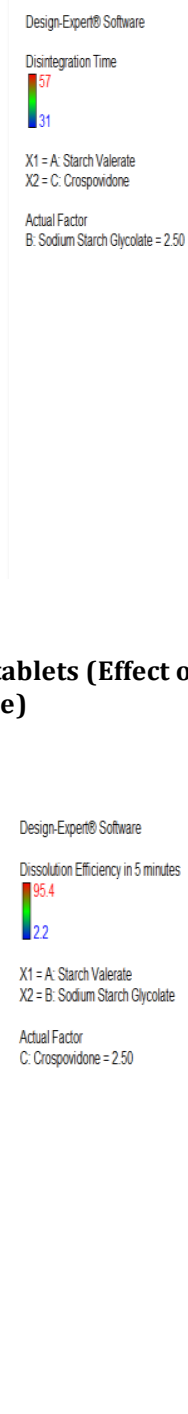

(A) Surface plot time)

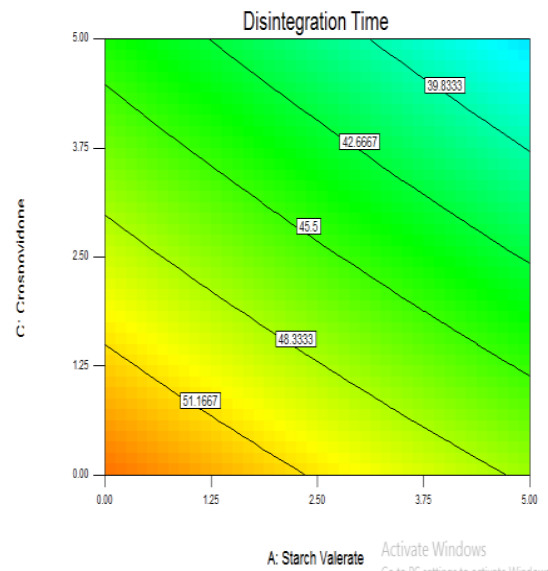

B) Contour plot

Fig. 5.2: A. Surface plot, B. Contour plot of Aceclofenac fast dissolving tablets (Effect of Starch Valerate and Crospovidone on disintegration

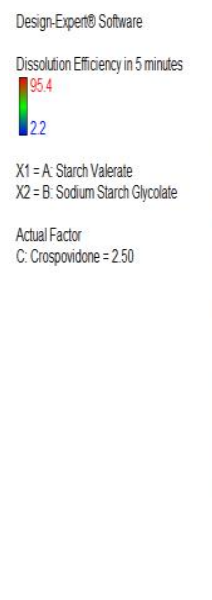

Fig. 5.3: A. Surface plot, B. Contour plot of Aceclofenac fast dissolving tablets (Effect of Sodium starch glycolate and Crospovid one on disintegration time) 


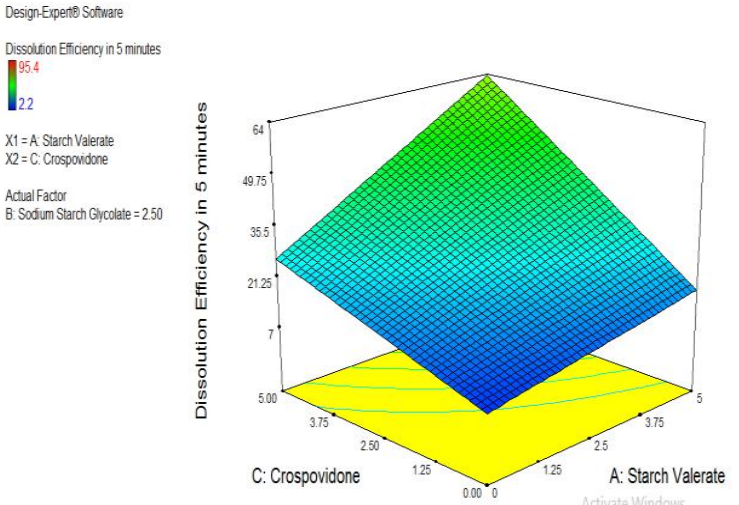

A) Surface plot

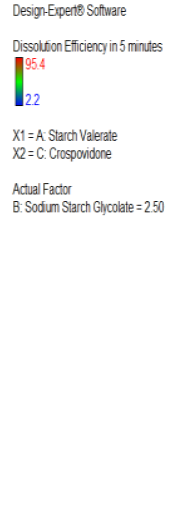

\section{B) Counter plot}

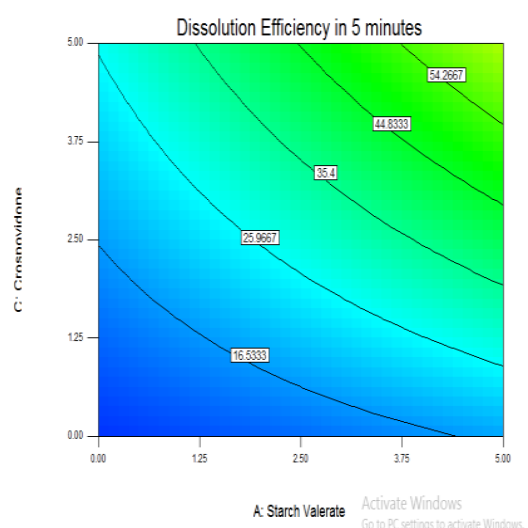

arh Valerate

Fig. 5.4: A. Surface plot, B. Contour plot of Aceclofenac fast dissolving tablets (Effect of Sodium starch glycolate and Crospovidone on dissolution efficiency in 5 min)

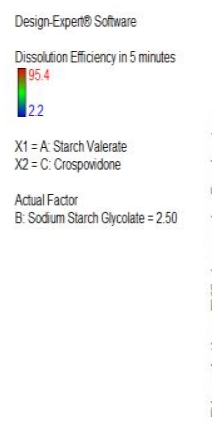

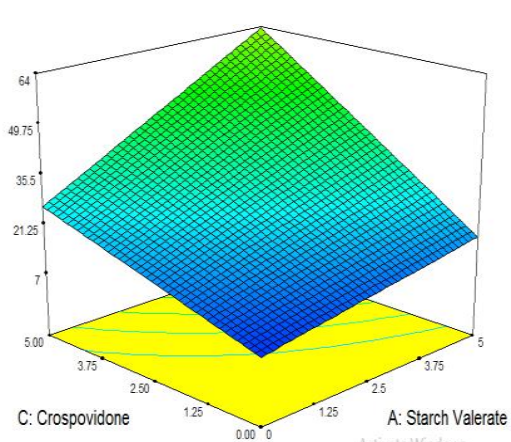

A) Surface plot

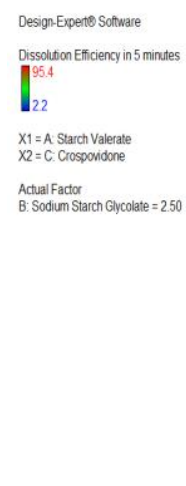

(1)

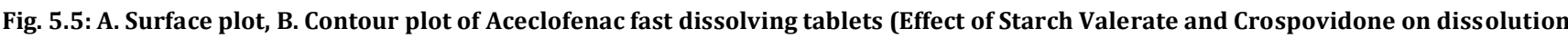

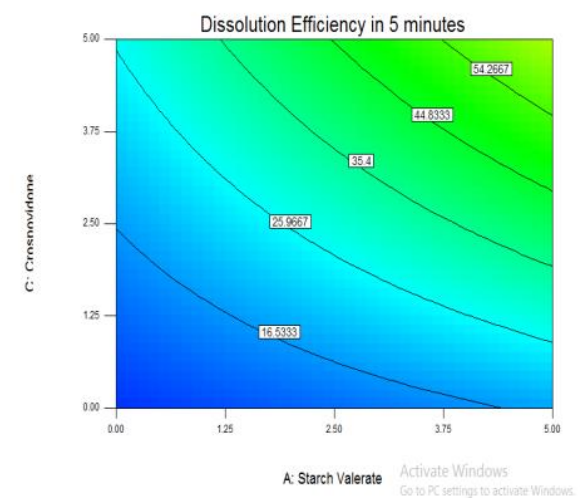

B) Counter plot

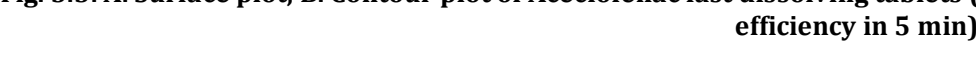

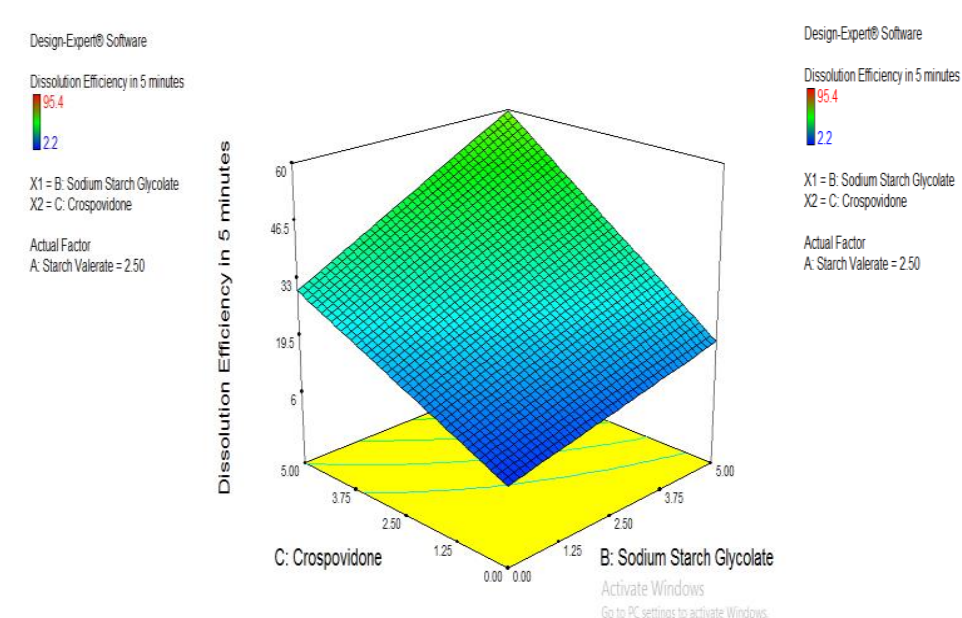

A) Surface plot

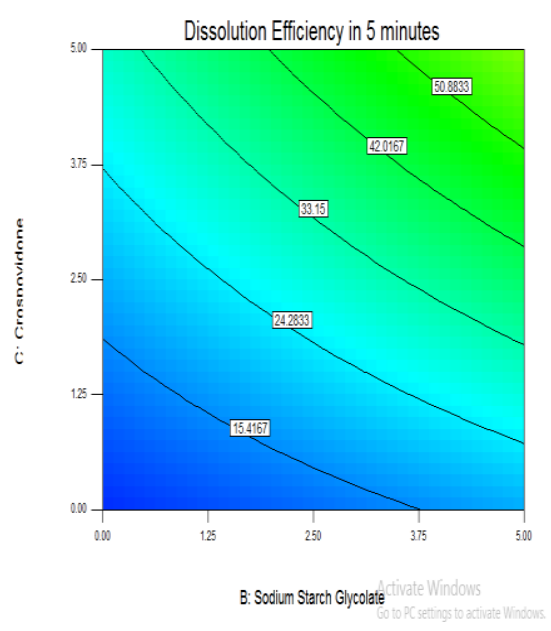

B) Counter plot

Fig. 5.6: A. Surface plot, B. Contour plot of Aceclofenac fast dissolving tablets (Effect of Sodium starch glycolate and Crospovidone on dissolution efficiency in 5 min)

The response surface plots and contour plots reveal that, with the increase in concentration of starch valerate (A), sodium starch glycolate (B) and crospovidone (C), the disintegration time decreases. The effects of A and B on disintegration time were shown in fig 5.3. The contour plots were found to be linear up to certain extent, there after they were non-linear. From the contour plot in fig. 
5.3, it was determined that a less disintegration time can be obtained with A-level range between 3.75 to $5 \%$ and $\mathrm{B}$ level range from 3.75 to $5 \%$ The effects of $\mathrm{B}$ and $\mathrm{C}$ were shown in fig. 5.4, where the contour plots were found to be linear indicating linear relationship between B and C. From the contour plots, the linearity was found indicating the linear relationship between $\mathrm{B}$ and $\mathrm{C}$. Also, it was determined from the contour plot (fig. 5.4) that, the less disintegration time was obtained with B-level in between 3.75 to $5 \%$ and C-level range from 3.75 to $5 \%$ The effects of $\mathrm{A}$ and $\mathrm{C}$ were depicted in fig. 6.5 , the contour plots were almost found to be linear indicating a linear relationship between $\mathrm{A}$ and $\mathrm{C}$. From the contour plot, it was determined that, less disintegration time was obtained with A-level in between 3.75 to $5 \%$ and C-level between 3.75 to $5 \%$. From this we can conclude that, less disintegration time can be achieved when the factor-A was used in the concentration range from 3.75 to $5 \%$ B and C-levels in the range of 3.75 to $5 \%$ of the total weight of the tablet.

The response surface plots and contour plots reveal that, with the increase in concentration of starch valerate (A), sodium starch glycolate (B) and crospovidone (C), the dissolution efficiency in 5 min increases. The effect of A and B on dissolution efficiency in 5 min were shown in fig. 5.6, the contour plots were found to linear to the maximum extent. From the contour plot, it was determined that, more dissolution efficiency can be obtained with A-level range at 3.75 to $5 \%$ and $B$-level range 3.75 to $5 \%$. The effects of $B$ and C were depicted in fig. 5.7, where the contour plots were found to be linear, indicating the linear relationship between B and C. From the contour plot, it was determined that, more dissolution efficiency can be obtained with B-level range between 3.75 to $5 \%$. The effects of $A$ and $\mathrm{C}$ were shown in fig. 5.8, where the contour plots were found to be linear, indicating the linear relationship between $\mathrm{A}$ and $\mathrm{C}$. From the contour plot, it was determined that, more dissolution efficiency in 5 min can be obtained in A-level range between 3.75 to $5 \%$ and $\mathrm{C}$-leve in a range between 3.75 to $5 \%$.

\section{CONCLUSION}

The prepared starch valerate was found to be fine, amorphous and free-flowing powder. Also, its physical and micromeritic properties were analysed indicated good flow and compressibility properties which were needed for a solid dosage form to manufacture. Potato starch was amorphous in nature whereas the prepared starch valerate was amorphous, fulfilling the aspects of superdisintegrant characteristics, hence starch valerate, a novel superdisintegrant can be used as a superdisintegrant in the formulation of fast dissolving tablets.

From the above data, the superdisintegrants that to be used in fast dissolving tablets to have less disintegration time and more dissolution efficiency in $5 \mathrm{~min}$ were; factor-A i.e., Starch Valerate $5 \%$, factor-B i.e., Sodium starch glycolate $5 \%$ and factor-C i.e., Crospovidone were found to be the ideal concentrations to formulate into fast dissolving tablets.

\section{ABBREVIATION}

M-Molar, NaOH-Sodium Hydroxide, ${ }^{\circ} \mathrm{C}$-Degree Centigrade, \#Number, pH-Potential of hydrogen, ml-millilitre, S. I-Swelling Index, W/V-Weight/Volume, LBD-Loose bulk density, TBD-Tapped bulk density, FTIR-Fourier Transform Infrared Spectra.

\section{FUNDING}

Nil

\section{AUTHORS CONTRIBUTIONS}

All the authors have contributed equally.

\section{CONFLICT OF INTERESTS}

Declared none

\section{REFERENCES}

1. Sanket Kumar, Shiv KR Garg. Fast dissolving tablets (Fdts): current status, new market opportunities, recent advances in manufacturing technologies and future prospects. Int J Pharm Pharm Sci 2014;6:22-35.

2. Ashish Masih, Amar Kumar, Shivam Singh, Ajay Kumar Tiwari. Fast dissolving tablets: a review. Int J Curr Pharm Res 2017;9:8-18.

3. Anupam Roy. Orodispersible tablets: a review. Asian J Pharm Clin Res 2016;9:19-26.

4. Sundeep Mupparaju, Vidyadhara Suryadevara, Sailaja Yallam, Sandeep Doppalapudi, Sasidhar Reddyvallam LC, Ramu Anne. Formulation and evaluation of dolutegravir sodium solid dispersions and fast dissolving tablets using poloxamer-188 and jack fruit seed starch as excipients. Asian J Pharm Clin Res 2019;12:181-90.

5. Kalindi Chauhan, Rakesh Solank, Shivani Sharma. A review on fast dissolving tablets. Int J Appl Pharm 2018;10:1-7.

6. Aher Smita S, Saudagar RB, Shinde Mayuri S. Review: fast dissolving tablet. Int J Curr Pharm Res 2018;10:5-12.

7. Hazarika JNR, P Deb. Formulation evaluation and optimization of immediate release tablet of aceclofenac by direct compression method. Int J Curr Pharm Res 2017;9:118-22.

8. Shaikh Siraj, Syyed Nazim, Gomase Pravin, Shaikh Afasar, Quazi Majaz. Formulation and evaluation of aceclofenac fast dissolving tablets. Int Res J Pharm 2011;2:100-5.

9. Shailendra Singh Solanki, Rashmi Dahima. Formulation and evaluation of aceclofenac mouth-dissolving tablets. J Adv Pharm Technol Res 2011;2:128-31.

10. R Santosh Kumar, T Naga Satya Yagnesh, V Goutham Kumar. Optimisation of ibuprofen fast dissolving tablets employing starch xanthate using $2^{3}$ factorial design. Int J Appl Pharm 2017;9:51-9.

11. R Santosh Kumar, $\mathrm{T}$ Naga Satya Yagnesh. Synthesis, characterization and evaluation of starch xanthate as a superdisintegrant in the formulation of fast dissolving tablets. Int J Appl Pharm 2018;10:249-58.

12. R Santosh Kumar, Ankita Gosh. Design, optimisation and evaluation of piroxicam fast dissolving tablets employing starch tartrate-a new superdisintegrant. Int J Appl Pharm 2019;11:89-90.

13. R Santosh Kumar, Sahithi Mulidi. Optimization of statistically designed aceclofenac fast dissolving tablets employing starch glutamate as a novel superdisintegrant. Int J Appl Pharm 2020;12:77-88.

14. Vivek Dave, Sachdev Yadav, Swapnil Sharma, Pushpendra Vishwakarma, Nasir Ali. Novel approach of aceclofenac fast dissolving tablet. Pak J Pharm Sci 2015;28:37-41.

15. C Mallikarjuna Setty, DVK Prasad, VRM Gupta, B Sa. Development of fast dispersible aceclofenac tablets: effect of functionality of superdisintegrants. Indian J Pharm Sci 2008;70:180-5.

16. Keshav R Deshmukh, Sunil K Jain. Development of aceclofenac mouth dissolving tablets using solid dispersion technique: in vitro evaluation. Ind J Pharm Edu Res 2012;46:97-104.

17. Jyotsana Madan, AK Sharma, Ramnik Singh. Fast dissolving tablets of Aloevera gel. Trop J Pharm Res 2009;8:63-70.

18. Kalpesh Gaur A, Lalit K, Tyagi A, ML Kori, CS Sharmab, RK Nema. Formulation and characterization of fast disintegrating tablet of aceclofenac by using sublimation method. Int J Pharm Sci Drug Res 2011;3:19-22.

19. Anas Bahnassi, Diana Zidanb. Formulation and evaluation of aceclofenac fast dissolving tablets using foam granulation technique. Indo Global J Pharm Sci 2012;2:342-7.

20. Garala Kevin C, Ekshinge Vinit B, Jarag Ravindra J, Shinde Anil J. Fast-disintegrating aceclofenac tablets: formulation development using simplex lattice design. Thai J Pharm Sci 2008;32:77-81. 